\title{
BIOLOGICAL ACTIVITY OF EXTRACTS FROM THE MYCELIUM OF MEDICINAL MUSHROOM INONOTUS RHEADES
}

\author{
Borovskii G.B. ${ }^{1,2 *}$, Borovskaya M.K. ${ }^{1,2}$, Gornostay T.G. ${ }^{1}$ \\ ${ }^{I}$ Siberian Institute of Plant Physiology and Biochemistry, Siberian Branch of RAS, ul. Lermontova, 132, 664033, \\ Irkutsk, Russia; \\ ${ }^{2}$ The Irkutsk Scientific Center of SB RAS, Siberian Branch of RAS, ul. Lermontova, 134, Irkutsk, 664033, Russia: \\ *Corresponding Author Borovskii G.B. ${ }^{1,2}$, e-mail: borovskii@ sifibr.irk.ru;
}

Received February, 2018; Accepted March, 2018; Published April, 2018;

doi: https://doi.org/10.31407/ijees837

UOI license: http://u-o-i.org/1.01/ijees/07057550

\begin{abstract}
The search for bioactive natural compounds potentially having antitumor activity - important problem of modern science. We have previously demonstrated high in vitro antiradical activity of water ethanol extracts (WEE) from the mycelium of Inonotus rheades. In the present study we evaluated the effect of 30\% and $70 \%$ of WEE from mycelium I. rheades on the cell culture of human tumor cells HEp-2. 50\% cell death is achieved after 24-h incubation in $53 \mu \mathrm{g} / \mathrm{ml} \mathrm{70 \%} \mathrm{WEE} \mathrm{(dry} \mathrm{weight),} \mathrm{whereas} \mathrm{30 \%} \mathrm{WEE} \mathrm{at} 550 \mu \mathrm{g} / \mathrm{ml}$ only, i.e. an order of magnitude difference between the concentrations, which indicates that high cytotoxic activity was shown WEE a radical change in the qualitative composition of extractives with increasing ethanol concentration. Incubation of cells with $250 \mathrm{mM}$ $\mathrm{H}_{2} \mathrm{O}_{2}$ resulted in approximately $40 \%$ cell death, whereas pre-incubation with both $30 \%$ and $70 \%$ of WEE resulted in $100 \%$ survival of cells in a large range of concentrations. This indicates a WEE protective effect under oxidative stress. Thus, WEE of the mycelium I. rheades in high concentrations exhibit cytotoxic activity. At the same time, a wide range of concentrations extracts can neutralize the oxidative stress and cell death caused by the addition of $\mathrm{H}_{2} \mathrm{O}_{2}$.
\end{abstract}

Key words: antioxidant activity, cytotoxic activity, Inonotus rheades, mycelium 